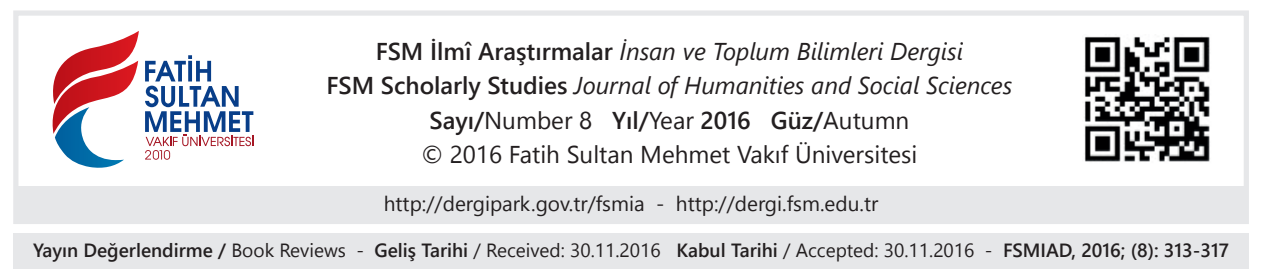

\title{
Behiştî Ahmed Çelebi, Târîh-i Behiştî: Vâridât-ı Sübhânî ve Fütûhât-ı Osmânî (791-907 / 1389-1502) II, haz. Fatma Kaytaz,
} Ankara: Türk Tarih Kurumu, 2016, 9789751631916, 419 s. İlhami Danış*

Osmanlı Tarihinin birincil kaynaklarının gün yüzüne çıkarılıp araştırmacıların istifadesine sunulması; tarihsel süreçlerin doğru anlaşılması ve yorumlanması ve bilgilerin mukayese edilebilmesi açısından büyük önemi haizdir. Osmanlı tarihçiliğinin gelişim sürecinde II. Bayezid devri önemli bir süreçtir. Padişahın ilim ehlini himaye etmesi ve onları Osmanlı tarihi ile ilgili eserler telif etmeye teşvik etmesi bu dönemde yazılan eserlerin sayısı ve niteliği anlamında önemli bir kaynak oluşturmuştur. Osmanlı tarih yazıcığının önemli isimlerinden Âşıkpaşazâde, Tursun Bey, Neşrî, Oruç Bey ve Behiştî Ahmed Çelebi II. Bayezid döneminde eserlerini telif etmişlerdir. II. Bayezid'in bu himayesi hem edebi hem de tarihi açıdan değerli eserlerin ortaya çıkmasına vesile olmuştur.

Osmanlı tarihine dair bu eserlerin birçoğu transkripsiyon ve değerlendirmeyle, bazıları da günümüz Türkçesi ile sadeleştirilerek yayınlanmıştır. Özellikle doktora çalışmalarına konu olan bu eserlerin, doktora sonrası yayına dönüştürülmesi Osmanlı tarihi üzerine çalışan araştırmacılar için büyük bir hazine değerindedir. Fatih Sultan Mehmet Vakıf Üniversitesi Edebiyat Fakültesi Tarih Bölümü ögretim üyelerinden Yrd. Doç. Dr. Fatma Kaytaz'ın doktora konusu olan ve doktora sonrası ulaşılan yeni bilgiler eşliğinde düzenlenerek Türk Tarih Kurumu tarafından basılan Tarih-i Behiştî çalışması, bu minvalde önemli bir yayın olarak araştırmacıların istifadesine sunulmuştur.

II. Bayezid dönemi tarihçilerinden olan Behiştî Ahmed, eserini himayesinde yetiştiği II. Bayezid'in emriyle yazmıştır. Eserinde ilk Osmanlı padişahı Osman

* Öğr. Gör., Fatih Sultan Mehmet Vakıf Üniversitesi Edebiyat Fakültesi Tarih Bölümü, İstanbul/ Türkiye, idanis@fssm.edu.tr 
Gazi'den II. Bayezid'e, sekiz Osmanlı padişahının dönemlerini anlatmaktadır. Her padişah dönemi "Sifr" adı verilen bölümlerde ele alınmıştır. (Bu adlandırma Fatma Kaytaz tarafindan da belirtildiği gibi farklı tarihçiler tarafından da kullanılmıştır; İbn Kemal tarafından "Defter", İdris-i Bitlisî tarafından da "Ketibe" vb.)

Eserin II. cilt olarak adlandırılmasının da oldukça önemli bir bilgiye erişilmesinden sonra gerçekleştirildiğini öğreniyoruz. Kaytaz, doktora çalışmasından sonra ilk üç Osmanlı padişahını anlatan bölümün bir nüshasının tespit edildiğini $^{1}$ ve tespit edilen bu nüshanın I. cilt olarak çalışıldığını, bu cilt sayesinde ise bazı yeni bilgilere erişildiğini belirtmektedir. Bu yeni bilgilerden en önemlisi ise Behiştî Ahmed'in eserine Vâridât-ı Sübhânî ve Fütûhât-ı Osmânî ismini vermiş olduğudur.

Behiştî Ahmed'in yayına hazırlanan II. cildi, Yıldırım Bayezid'den II. Bayezid'e kadar olan süreci kapsamaktadır. "Giriş", "metin” ve "dizin" olarak üç bölümden oluşan yayının "giriş” kısmında Behiştî Ahmed Çelebi'nin hayatı ve eserleri konu edilmiştir. Özellikle doğum tarihi ${ }^{2}$ ve ismi ile ilgili farklı görüşlerin olduğu Behiştî Ahmed Çelebi'nin en çok bilinen özelliği şairliğidir. Şiirlerinde "Behiştî" mahlasını kullanan şairin isminin Ahmed olduğunu da Leylâ vü Mecnûn adlı mesnevisinden öğrenmekteyiz.

II. Bayezid döneminde yaşayan Behiştî Ahmed, babasını erken yaşta kaybettikten sonra padişahın himayesinde yetişmiş ve onun hizmetinde bulunmuştur. Sarayda yetişmiş olması onun iyi bir eğitim aldığını göstermektedir ki, eserleri, Arapça ve Farsça'ya hâkimiyeti ve şiirleri bunu doğrulamaktadır. Eserleri arasında Hamse'si -ki, Türk edebiyatında Hamse tertip eden ilk şairlerden biri olarak bilinmektedir- önemli bir yere sahiptir. Şuara tezkirelerinde Behiştî Ahmed'in Hamse'si ile ilgili çok sayıda bilgi bulunmaktadır ve günümüzde birçok çalışmaya da konu olmuştur. Yakın zamanda bir Divanı'nın da bulunduğunu belirten Kaytaz, Behiştî’ye atfedilen bazı şerhlerin varlığına da dikkat çekmektedir.

Hazırlanan yayında Behiştî Tarihi detaylı bir şekilde incelenmiştir. Bu noktada eserin nüshaları, bu nüshaların içeriği ve nüshaların nasıl kullanıldığı aktarılmıştır. Metinde eserin British Library Add. 7869 nüshası ile Topkapı Sarayı Müzesi Kütüphanesi Revan nr. 1270 nüshası esas alınmıştır. Bu tarz çalışmalarda en önemli hususlardan biri, eserin kaynaklarının incelenmesidir. Eser üzerinde çalışanların karşılaştığ 1 en temel sorun ise eserin içerisinde kullanılan kaynakların isminin belirtilmemesidir. Dolayısıyla kaynak tespiti yapma noktasında titiz

1 Bu nüsha bir makale ile tanıtılmıştır; Müjgan Çakır/Fatma Kaytaz, "Behiştî Ahmed Çelebi'nin Yazdığı Osmanlı Tarihi'nin (Vâridât-1 Sübhânî ve Fütûhât-1 Osmânî) Bilinmeyen Eksik Kısmına Dair", Turkish Studies-International Periodical For The Languages, Literature and History of Turkic Volume 8/11 Fall 2013,p. 99-112, Ankara/ Turkey.

2 Yazara göre en doğru tarih H.874 / M.1469/70 olarak kabul edilebilir. 
bir çalışma gerekmektedir. Kaytaz’’n kitapta belirttiği üzere özellikle eserde “dirler", rivâyet iderler" şeklinde bilgi aktaran cümleler eserin kaynaklarına ulaşma noktasında önemli bulgulardır. Ayrıca Behiştî Tarihi'nde "mervîdür ki”, "hikâyet ideler ki" gibi kelimeler bilginin başka bir kaynaktan (yazılı veya sözlü) alındığına işaret etmektedir. Bu çerçevede eser üzerinde yapılan incelemede Behiştî Ahmed'in kullandığı yazılı kaynaklar tespit edilmiş, bu kaynaklar örnekleriyle beraber mukayeseli şekilde değerlendirilmiştir. Buna göre Behiştî Ahmed, eserinde Osmanlı tarih yazıcılığı açısından önemli yere sahip olan birçok kaynaktan istifade etmiştir. Bu kaynaklar; İdris-i Bitlisi, Neşrî, İbn Kemal, Tursun Bey, Ruhî Çelebi, Oruç Beğ, Gazavatnâme ve Anonim Tevârîhi Âli Osmanlar olarak sıralanmaktadır. Kaytaz bu eserlerin sıralamasında en çok istifade edilene göre bir tercihte bulunmuştur. Her kaynağın Behiştî Tarihi ile mukayesesi yapılmış ve kaynaklardan istifade edilen hususlar araştırmacıların kolay ulaşabileceği bir sitemle aynı sayfada karşılıklı sütunlarda gösterilmiştir.

İslam Ansiklopedisindeki (EI2, I, 1210) "Bihishti" maddesini yazan ve Osmanlı tarihi ile ilgili çeşitli araştırmaları olan V.L. Manege'ın, Behiştî Tarihi'nin en önemli kaynağı olan İdris-i Bitlisi'nin Heşt Bihişti ile benzerliğine dair düşüncesinin ${ }^{3}$ tamamen yersiz olmamakla birlikte oldukça iddialı olduğunu belirten Kaytaz, çalışmasında Behiştî Ahmed'in, Heşt Bihişt'ten aldığı bilgilerin yanı sıra farklı kaynaklardan da istifade ettiğini ayrıca tamamen kendi gözlemlerine dayanan orijinal bilgiler de içerdiğini örneklerle aktarmaktadır. Behişti Tarihi incelendiğinde müellif, eserinde kendi müşahedeleri yanında döneminde yaşayan önemli şahısların anlattıklarına da yer vermektedir. Şüphesiz bu bilgiler dönemi yaşayanların gözlemleri olması hasebiyle oldukça önemlidir ve eserin önemine katk1 sağlamaktadır.

Behiştî Ahmed'in eserini telif ederken kullandığı kaynakların Behiştî Tarihi ile karşılaştırılması detaylı bir şekilde ele alınmıştır. Burada, Behiştî Ahmed'in kaynaklardan ne şekilde istifade ettiği örneklerle aktarılmıştır. Böylece eser ve kaynakları arasındaki bağlantı ortaya çıkarılmıştır. Verilen örnekler kısa bir değerlendirme (kaynak ile eser arasında bilginin ne şekilde kullanıldığ 1 ve dil, üslup benzerliği ve farklılıkları) ile aktarılmış olup araştırmacıların kolay bir şekilde karşılaştırma yapmalarına imkân sağlanmıştır.

"Kaynak değeri” başlı̆̆ kitabın en önemli kısımlarından birisidir. Burada Behiştî Tarihi'nin özgünlüğü değerlendirilmektedir. Kaytaz, Behiştî Tarihi'nin, özellikle en çok istifade ettiği İdrisi Bitlisi ve Neşri tarihlerinin kopyası olmaktan ziyade kendine özgü bir Osmanlı Tarihi olduğunu şu maddelerle gerekçelendirmektedir:

3 Menage, Behişti Tarihinin İdrisi Bitlisi'nin takipçisi olduğunu ve ondan daha fazla bilgi içermediğini öne sürmektedir. 
- Kullandığı bilgileri kaynaklardan aynen nakletmemesi, farklı kaynaklarla mukayese edip eksiklikleri tamamlamış olması,

- II. Murad dönemine ait bazı bilgilerin doğrusunun ilk defa Behiştî tarihinde yer alması ve Uzunçarşı11, İnalcık gibi tarihçilerin bu bilgileri Behiştî Tarihi'ni kaynak göstererek kullanmaları,

- II. Bayezid dönemi ile ilgili kendi müşahedelerini (II. Bayezid'in Çöke Yaylası'nda elçi kabulü, Arnavutluk Seferi vd.) veya bizzat nakleden kişilerden elde ettiği bilgileri kullanması,

- II. Bayezid dönemine ait diğer kaynaklarda eksik, hatalı olan bilgileri (Karagöz Paşa'nın idamı, Eflak voyvodasının Osmanlı ordusuna ilhakı vb.) doğru şekilde aktarıyor olmas1,

- Hiçbir kaynakta yer almayan özgün bilgiler veriyor olması.

Eserin metin bölümünün fihristi bilgiye erişilmesini kolaylaştıracak şekilde yayının "İçindekiler" kısmında yer almaktadır. Metindeki başlıklar incelendiğinde Behiştî Ahmed'in özellikle gazâ ve fetihlere geniş yer verdiği görülmektedir. Bunun yanı sıra cülus törenleri, elçi kabulleri, padişahların ve çocuklarının düğünleri ile ilgili bilgiler de araştırmacılar için önemlidir. Behişti Ahmed, şair olmasının etkisiyle eserinde edebî bir üslup kullanmış, Farsça ve Arapça sıfat grupları ile uzun tasvirlere yer vermiş̧tir. Yazarın da belirttiği gibi padişahların tahta çıkışları, savaş sahneleri, kalelerin ihtişamı, baharın gelişi gibi olaylarda geniş tasvirlere, Farsça Arapça ve Türkçe beyitlere yer vermiştir. Eser, şiirleri, dili ve tasvirleriyle edebî açıdan da incelenmeye değerdir. Her padişah dönemi uzun manzumeler ile başlamaktadır. En uzun manzumeler ise II. Bayezid, Fatih Sultan Mehmed ve I. Bayezid dönemine aittir. Şiirlere sadece bölüm başlarında rastlanmaz. Metin içerisinde çok sayıda beyit ve mesnevi yer almaktadır. Behiştî’nin şiirlerine örnek olması hasebiyle Fatih'in düğününün anlatıldığı kısımda yer alan bir beyit ile II. Bayezid'e ithafen yazdığı uzun manzumeden kısa bir örneği paylaşalım:

Beyt

Gelürler bir yire ol iki cânân

Biri Belkîs olur biri Süleymân

Manzume

Ne sultânımış şâhumuz bileler

Anup cân ü dilden du'â kılalar

Selâtînün oldur ser-i defteri

Şeh ol pâdişehler anun leşkeri 
Kemâli kemâlinde kadri celîl

Şifâlar bulur şefkatinden 'alil

Kime kim ola zerrece himmeti

Ziyâde olur gün gibi rif'ati

Vay ana ki kahrina mazhar ola sezâ

Kalanı yanında anun kethuzâ

Sonuç olarak, Behiştî Ahmed ile ilgili olarak kaynaklarda Hamse'si ile ilgili bilgiler yer alırken tarih eseri ile ilgili bilgi yer almamıştır. Behiştî Tarihi'ni ilk kullanan Uzunçarşılı olmuştur. O zamana kadar pek bilinmemesinin sebebi olarak Kaytaz, Behiştî'nin eserini II. Bayezid'e takdim etme firsatı bulamamasını gösterir. Eser günümüzde artık makalelere konu olmaktadır. İlk defa tüm metni ve nüshaları ile Fatma Kaytaz tarafından doktora tezi olarak ele alınmış ve ardından yeni bilgilerle yayına dönüştürülmüştür. Yayının sonunda yer alan indeks -ki, bu tarz çalışmalar için oldukça önem arz eder- eser üzerinde çalışmayı kolaylaştırmaktadır. Bu yayına kadar eserin muhtevası hakkında çok fazla bilgi sahibi olunmaması bile çalışmayı önemli kılmaktadır. 